\title{
Sinking, Swimming or just Treading Water. The Olympic Legacy from London 2012 - 4 Years On. Has it made any difference? Pupil Voice and an Analysis of Swimming Provision
}

\author{
By Barry Paraskeva Costas*
}

\begin{abstract}
This paper examines whether the Olympic Legacy has made any difference to the children of Hackney in East London in terms of swimming and physical activity provision, from the children's point of view. In what has become an issue of great concern to teachers (and parents), over the last 25 years, many children have been identified as not being able to swim at all, yet the National Curriculum in England stipulates that all children must be able to swim at least 25 metres by the age of 10 and 11 years old at the latest. As part of the London 2012 Olympic and Paralympic Games spectacle, a magnificent Olympic Aquatic Centre was built on the Olympic Park, now known as The Queen Elizabeth Olympic Park. The legacy of the games, stated that the sporting resources left after the games would be made available to the general public including local children and schools, as a means of encouraging people both young and old, to become more physically active, including swimming as a sport and leisure activity. The data collected contributes to an existing body of knowledge where the vast majority of the work on pupil and learner voice has been concerned with the core school subjects and with secondary schooling. The re-emergence of the pupil voice as a pedagogical approach to inform curriculum design is encouraged throughout this paper.
\end{abstract}

Keywords: Children, Learning and Pupil Voice, Pedagogy, Physical Education, Swimming

\section{Introduction}

This case study gave a voice to 52 children from two different classes in the same school in the spring of 2016, through the use of questionnaires and follow up interviews. The aim was to explore what the children thought about the Olympic and Paralympic Games (OPGs) and swimming, with a view to illuminating and informing the current policy, practice and research in relation to the aims which under-pin the OPG legacy. Children's voices from year 6,10 and 11yrs old, have been conspicuously absent from any significant discussions about their health, sport, physical activity and swimming in particular, over the last twenty years. See for example reports from The Department for Children Schools and Families (2009), The Westminster Education Forum (2012). This paper gives a view of the OPG legacy and sporting opportunity and provision from the recipient's perspective by including them in a discussion about their physical education (and swimming provision and entitlement). By including the children in such a discussion teachers can be seen to value their voices as pedagogical tools, and in turn this paper shows that through democratising the discussion, the children are more than just "empty vessels" and were able to offer informed views at year 6. This paper builds upon earlier pieces of research, Costas (2011), which formed the

\footnotetext{
${ }^{*}$ Senior Lecturer, University of Hertfordshire, UK.
} 
basis of a doctoral thesis in the run up to the Olympic and Paralympic games in London in August 2012, and subsequent research on Olympic legacy (Costas 2014, 2016). The researcher again takes a constructivist-interpretivist stance, Geertz (1973), Schwandt (1994), Guba and Lincoln (1994) and Burr (1995). The constructivist-interpretivist position looks at the unique or individual viewpoint, and then endeavours to construct general "trends" based on what the individual is saying, to form more robust arguments, as opposed to isolated random responses. Schwandt (1994: 233) writes of constructivism and interpretivism referring to them as sensitising concepts, which steer researchers towards a particular outlook. He states "Proponents of these persuasions share the goal of understanding the complex world of lived experiences from the point of view of those who live it". In this piece of research, questionnaires and follow up interviews were used to give a voice to 52 children from Stoke Newington in Hackney East London with the aim of exploring what the children thought about the Olympics, with a goal of widening and informing the current policy, practice and research in relation to the National Curriculum (NC), Olympic legacy, Physical Education (PE), sporting opportunity and swimming provision in particular. As White $(2004,2007)$, Lawton (1996, 2000), Simons (1987, 1999), and the sociologists Fielding (2004, 2008) Apple (1995), and Ball (1993) have all argued, children must be included to a much greater extent in their own learning, if education is to be successful in the $21^{\text {st }}$ century. As Figure 1 shown below demonstrates, a broad range of academics make this point although their expertise emanates from different academic fields of enquiry. They all argue that in education we need to stop viewing the young learner as a passive recipient of knowledge, and to place them at the heart of their own learning. Through the concept of the Olympic legacy pupil voice is used to illuminate and broaden the discussion.

The children's voices, still also absent from discussions about the Olympic legacy, gave an overview of the curriculum and the Olympic and Paralympic games (OPGs) from their perspective. Through the vibrancy of their voices, their views on the Olympic legacy, primary PE, Sport and swimming were examined, and in so doing showed that through democratising the discussion, the children were more than just "blank slates", and were able to offer informed views. This paper then, as part of an going longitudinal study, examines whether the excitement, optimism and the overall positivity recorded by the children prior to 2012 in relation to the OPGs, the greatest show on earth ${ }^{1}$ coming to London in 2012 has come to fruition in any way. This is important because as White (2004, 2007), Lawton (1996, 2000), Fielding (2004, 2008), Simons (1987, 1999), Apple (1995), and Ball (1993) have argued their voices need to be included as we move towards the third decade of the $21^{\text {st }}$ century. To date, these voices have not been heard and yet they are to be the generation who will inherit the legacy in the future. Has the legacy of the OPGs influenced, or impacted on giving the children

\footnotetext{
${ }^{1}$ This is a common phrase often used by many sports commentators and the popular press to describe the Olympic and Paralympic games. The phrase originates from the 1952 film called "The Greatest Show on Earth" and stars Betty Hutton and Cornel Wilde in an American drama film where the circus is centre stage. The film won Academy awards for best picture and best story and the film's box office remains among the highest grossing films in the USA and Canada.
} 
access to greater swimming provision the researcher wondered, and who better to ask than to ask the children themselves?

Figure 1. The Learners Voice as the Heart of Learning

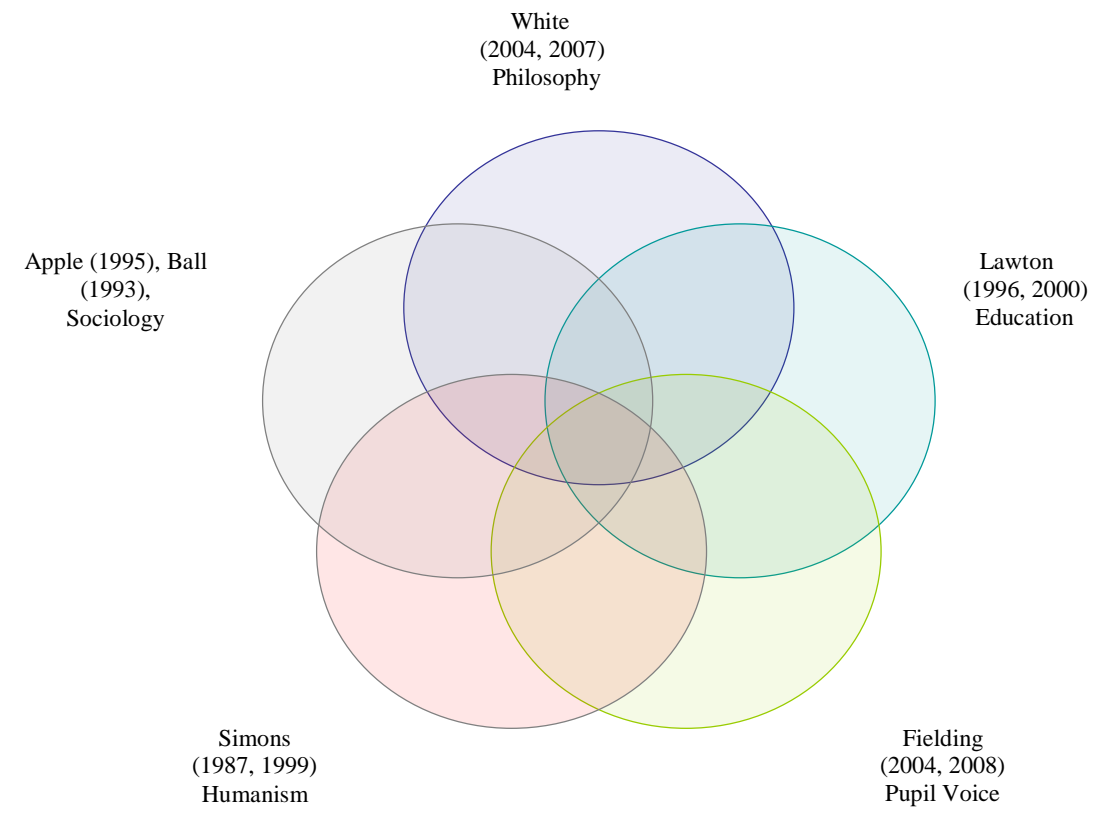

Source: Costas, 2011.

\section{Defining Olympic Legacy}

Defining legacy is notoriously difficult and complex. A legacy in the most literal sense is what someone, some body or something leaves behind after they have moved on or, changed position, or passed away. The use of the term legacy in the present context is as Piper and Garratt (2013) and Griffiths and Armour (2012) have argued, both informative yet also most problematic. Its most common usage refers usually to an intergenerational bequest, in which the receiver (or beneficiary) need only be passive. MacAloon (2008: 1984) identifies further problems in the application of the term in the context of the bi-lingual Olympic movement, because the "equivalent" in French is the word heritage. Whilst sharing some common ground in translation, the French term as argued by Piper and Garratt (2013) and MacAloon (2008), is more weighted towards the past arriving in the present as opposed to the more restricted English translation in the Olympic context of leaning towards creating the present which may or may not arrive in the future. As they argue in this French context, it cannot merely be a passive process. For an Olympic legacy to be of benefit to any inheritor, the individual or groups of individuals targeted to gain from the legacy have to be included and active, that is to say to play a role and 
understand their position within the whole process from start to finish. The researcher contends that sport policy, indeed Olympic legacy policy cannot be implemented in a vacuum outside of the wider society. An approach which does not work in tandem with the social groups it is seeking to influence cannot be successful and as Piper and Garratt (2013: 2) have argued, "such an approach to legacy achievement and widening sporting participation is naïve, and likely to be at best only partly successful." Legacy is usually interpreted as something positive but not necessarily always so. What of the enormous debt that Athens ${ }^{2}$ was riddled with after the games of 2004, or the underused resources of the less popular sports after Sydney 2000?

In terms of an Olympic legacy, there should always be an aspiration towards positivity across a range of criteria in line with the statute set out when the modern Olympic Games as we know them came into being in 1896 under the auspices of Baron de Courbetin. However on closer inspection the notion that the Olympic Games should leave a legacy, only really gains pace in the 1940 s and it is only from the post war years in the late 1940s that the word legacy appeared in the Olympics documentation (Torres 2011, McIntosh 2003, as cited in Gold and Gold 2008). A legacy in this context is what an Olympic city leaves behind after the Games have come and gone.

As part of "the bidding process" before the Olympic Games are awarded to a city, the International Olympic Committee (IOC) advocates that each bidding city for the OPGs must, from the outset, articulate in great detail how they will utilise the benefits from the event to bring long lasting, positive outcomes for the area and the citizens of the city. This process had begun in earnest for London 2012 as Lord Sebastian Coe working with the London Organising Committee for the Olympic Games (LOCOG) had a detailed vision and plan in place as early as 2005 when the host city elections were taking place. As Lee et al. (2013: 581) commented the vision for 2012 and beyond included:

"The regeneration of a massive industrial wasteland in East London, providing the local community with world class sporting venues to train, swim and compete in, new parks and residential areas, better transport connections and infrastructure, employment and business opportunities, and the creation of the next generation of sporting champions by inspiring young people everywhere to become more involved in physical activity". This vision was not going to be unproblematic, for as Vigor et al (2004) so astutely noted following the Olympic Games of Athens 2004, that an

\footnotetext{
${ }^{2}$ Many Greek Commentators have argued that in part many of Greece's economic problems stem from an over investment in the Games of 20004, and the legacy has never come to fruition. In January 2015 the left wing party SYRIZA of Alexis Tsipras came to power in Greece elected as a government against austerity measures imposed by the European Union and the Troika Bank (Tsipras 2015). Elsewhere as Toronto in Canada looked with interest at staging the 2024 Olympics, Chris Selley a Sports journalist warned in the National Post, "Montreal which staged the 1976 Summer Games, finally paid off the debt on the Olympic stadium in 2006 - 30 years later. (Au revoir Montreal, Kali' mera Athens, the risks are enormous.)" National Post, Wednesday $29^{\text {th }}$ July 2015, pp. A8 \& A12.
} 
investment on hard infrastructure like new sports facilities or railway terminals is not enough as the extent of an Olympic legacy. Vigor et al, (2004) argued that if long term benefits were to be delivered, policy makers must equally focus on softer infrastructure (the researcher's italics) such as community involvement, sports participation and employment and skills policy. As Wimbledon reminds us every year, we still have a lot to learn about using an elite sporting event to deliver sustained increase in grassroots participation. There is much that has been written about the Olympic legacy in recent times, see for example the work of Brunet (2009) and the Barcelona games, Cashman (2006, 2011) and the Sydney games, Brunet and Xinwen (2009) and the Beijing games, or Panagiotopoulou (2009) and the Athens games of 2004. What is evident is that all of these writers have argued that whilst there are many similarities between the host cities, there are also many differences, and any analysis of the success or failure of a legacy has to be viewed individually as no single template guarantees success for each and every venue. As Poynter $(2006,2009)$ hypothesised London 2012 would not be unproblematic even if lessons from previous Olympiads were heeded. Not dissimilarly, the title of Cashman's paper (2006) The Bitter-Sweet Awakening: The Legacy of the Sydney 2000 Olympic Games is most informative in itself.

Elsewhere lessons about successful legacies are also present. For example community involvement from the very beginning was vital to the very successful entrepreneur and motivational speaker Tim Smit (2002), Director of the Eden Project in Cornwall UK. He tells in his narrative how he actively sought out local expertise and harnessed community support for the project believing that this was a crucial aspect in making the initiative sustainable. In just over five years, Smit and his team turned what many people believed was a worthless, polluted un-useable site, into Britain's fifth largest tourist attraction. It attracts over a million visitors every year, has raised over 120 million sterling pounds, and invested over 500 million in the local economy.

The Eden Project continues to employ over 500 local people in an area which traditionally had high unemployment and has now, almost without wishing to, become a national example of a very successful sustainable regeneration project, that is to say everything that an Olympic legacy hopes to achieve. It will be insightful shortly to see whether the young people who grew up as part of the local Olympic community see the legacy of London 2012 in the same way as locals see the Eden Project. As Duran (2005) has shown, the Olympic Games of Barcelona 1992 are arguably the most successful games of the last 25 years, as the legacy there saw Reial Club Deportivo Espanol de Barcelona inherit the Olympic ${ }^{3}$ Stadium as their home, and the Barcellonetta

\footnotetext{
${ }^{3}$ At present in the autumn fall of 2016 it is West Ham United Football Club formerly of Upton Park who have moved into the Olympic Stadium in time for the beginning of the 2016-17 soccer season in August 2016. The stadium has already been re-named The London Stadium and the first Premiership game saw West Ham United defeat AFC Bournemouth 1-0.
} 
area of the city (formerly the Olympic village) is now home to hundreds of local people and their families, and such was the effectiveness of the long term strategy that underpinned the legacy that tourism still continues to thrive in Catalonia. Nello (1997) looks at the concept of the Olympic village and argues that to be successful it must be a common and shared experience, and the title of the research is most informative as it lists planning and sharing as key concepts of a legacy. The Olympic Village of Barcelona 92 in Olympic Villages: Hundred Years of Urban Planning and Shared Experiences.

\section{The Olympic Legacy and London 2012}

In 2008 the government published the draft of what the legacy for London 2012 would entail. The Department for Culture Media and Sport (DCMS) stated that the legacy would cover eight different aspects that would impact on not just local communities but communities across the entire UK. In what was a sixty page document, the researcher summarises the categories below:

1. The Regeneration of East London including all host boroughs. In this category it was envisaged that the Games would provide opportunities for jobs, business creation before, during, and after the Games had left town.

2. Venues. It was felt that by staging the games in this part of London that the most enduring aspect would be the regeneration of an entire community for the direct benefit of everybody who lives there.

3. Legacy for participation in Sport. With the Games being staged in London there was hope that more people of all ages would be inspired to do more sport across the entire UK.

4. Economic Legacy. ${ }^{4,5}$ It was anticipated that 7,000 full time jobs would be created in the construction industry, and that up to 12,000 jobs might be created as a result of legacy development.

5. Tourism - not unlike the vision set out and realised in Barcelona 1992, it was predicted that the net economic benefit from tourism would increase by $50 \%-70 \%$ over a seven to ten year period.

\footnotetext{
${ }^{4}$ Despite the fact that the London Delivery Authority had pledged to employ local people and to provide training and apprenticeships, creating a skills legacy for East London, figures released under the freedom of information act showed that 1 in 3 people employed at the main Olympic site were not local people. The building work had taken precisely 115 people off of local dole queues, but by contrast local boroughs have lost 93 companies employing 1,245 employees. Figures supplied by The London Delivery Agency 2nd June 2009 (Now known as The Olympic Delivery Agency available at https://www.olympicdeliveryagency).

${ }^{5}$ As the economic climate worsened and the "credit crunch" bit even harder for some, a number of large national employers have made staff redundant, and in June 2009, Reuters reported that there were now 2.26 million unemployed and job vacancies hit a record low in the UK. This was the highest figure since 1974 (Reuters News Agency, 18th June 2009, Retrieved from https://uk.reuters.co./news/uk).
} 
6. A Cultural Olympiad - although this is a comparatively new aspect of the Olympic legacy, it is a new and exciting feature which sits comfortably with the cultural diversity of East London. (This was envisaged as a four year period from 2008-2012, where celebrations of culture, which reflected the diverse communities of London and the UK was to be held.)

7. An Olympic Trust. Essentially this trust was going to be endowed with a total of $£ 40$ million in residual income and will be responsible for leaving a lasting legacy of the 2012 Games for future generations.

8. A legacy for the nations and regions. The vision here was that if these goals were achieved, there would be increased participation in sport, an increased awareness of the UK as a touristic destination, and a greater engagement with elite sport through contact with other national teams in training.

The aim of this study was to focus on the children's views on the regeneration of East London and their uptake in use of the new sport and swimming facilities, and whether this had impacted on increased numbers of children learning to swim or indeed develop existing aquatic skills.

\section{The Context of the Research}

Even with an understanding of the idiosyncratic nuances of the United Kingdom's (UK) education system, the structure of its National Curriculum (NC) remains bizarre. The NC in the UK (2013) is essentially hierarchal in format with the most important "perceived" subjects being termed as core subjects, which include English, Mathematics (and Science). All other subjects are listed as foundation subjects and are not given the same timetable "weighting" as the core subjects. The National Curriculum document consists of 224 pages and the core subjects are detailed in pages 9-181 (172 pages in total), whereas all the other 9 subjects are detailed from pages 182 to page 223 (41 pages in total), and Physical Education (PE) whilst being a statutory subject only merits 4 pages, listed as pages 220-223, and covers all four key stages of learning from 5-16 years old. Swimming and water safety is listed as a separate sub-heading and reads:

All schools must provide swimming instruction either in key stage 1 (57 yrs old) or key stage 2 (7-11yrs old). In particular, pupils should be taught to:

- Swim competently, confidently and proficiently over a distance of at least 25 metres.

- Use a range of strokes effectively such as front crawl, backstroke and breaststroke.

- Perform safe self-rescue in different water-based situations. The National Curriculum (Department of Education 2013: 222). 
There is no mention of providing Swimming provision for the older children at key stages 3 or 4, aged 11yrs and beyond, nor of swimming tuition in the Early Years Foundation Stage (EYFS aged 3-5years old). Equally there is no mention of supporting children who have not learnt to swim once they have left key stage 2 and moved on to Secondary schooling. Notwithstanding the heavy government emphasis on keeping our young people safe in and out of school, for example Every Child Matters (Department for Education and Skills 2003) and subsequent documentation, it seems odd that teaching a child to swim is not seen as an important life skill on an equal footing with literacy and numeracy and regarded as a core skill? The Amateur Swimming Association (ASA) ${ }^{6}$ revealed in May 2016, that around 200,000 children will leave their primary schools in the summer of 2016 being unable to swim, and of those 200,000 children, $40 \%$ had not even been offered the opportunity to learn to swim. The ASA extrapolate that over the next 10 years such alarming figures will lead to over two million non-swimmers. Moreover the ASA also reveals that drowning is the third most common form of accidental death in children (http://www.totalswimming. co.uk/pages/news).

In the context of this research, blame is not being apportioned to the schools directly, far from it, but it is clear that the education system is woefully failing many children dramatically in this respect. Historically local municipal swimming baths provided free access to all school's children during curriculum time, and this was paid for by the local education authority. Likewise transport to and from local swimming pools was provided free of charge by the education authority historically until the onset of privatisation in the UK in the late 1980s and 1990s onwards. Local swimming pools were discreetly turned into Leisure Centres, the bus services became private enterprises, and all had to be run at a profit. The net result was that schools are now being charged per child, per swimming session and that the transportation fees continue to increase on a yearly basis. Charges in London can vary from 50p per child to an excess of $£ 3$ per child per half hour session with tuition, and bus prices can reach close to $£ 100$ for a morning or afternoon drop off and return to school including waiting time. Clearly schools cannot afford this, and parental donations and sponsored challenges are very helpful but are not sustainable over a long period. The situation is compounded still further because some head teachers have argued that they cannot afford to lose an afternoon or morning every week, as the pressures to succeed in the national tests, the Standard Attainment Target tests (SATs) are so great that the heads fear for their jobs.

\section{Giving Pupils a Voice and Ethical Considerations - Methodology}

Pupil voice is seen as imperative throughout this paper as a means of valuing what the pupil has to say in their own right. That is not to say that

\footnotetext{
${ }^{6}$ Amateur Swimming Association (2016). Retrieved from goo.gl/IxZo8Y. [Accessed: 24th May 2016]
} 
everything that is said is always correct or indeed of value but as a pedagogical tool, pupil voice can be a very useful teaching aid. Penney (2004) calls for a radical refocus, and for a more flexible, interconnected and inclusive teaching approach which is geared to children's current and future lives with greater opportunities for choice given to schools and pupils. These views sit comfortably with those advocated by White (2004, 2007), and Robinson and Aronica (2015) in terms of making teaching and learning relevant for young people in the twenty first century. What better way to inform our practice as teachers (and policy makers) than to invite suggestions from the key stakeholders in the overall process, by asking the children themselves? As part of such a process to be made possible, Penney argues (2004: 149) that "educationalists may need to consider a radical re-orientation and re-structuring of their approach and in that process embark on a possibly uncomfortable view of their own professional identities". Moreover this challenge will involve moving away from the notion that children are empty vessels, blank slates or should be seen and not heard. ${ }^{7}$ The children of today are the adult citizens of tomorrow, and the researcher contends that they are capable of contributing to and taking a role in their own learning, where teaching should extend beyond out-dated boundaries like transmitting knowledge solely, and connect with the needs, interests, and lives of all children and their roles in the transformation of communities and societies. The twenty-first century in 2016 looks and feels like a very different place to thirty years ago, in so many different ways, and education is not an exception to that rule.

Prior to commencing the data collection in 2016, written agreement from the head teacher and the board of governors was sought and gained. All children and parents/guardians were given, and were required to complete, an informed consent form detailing the nature of the proposal and relevant background information. All involved had the right to withdraw at any time without prejudice. All parties involved were assured that all information collected, would remain strictly confidential and only used for the purpose of this research.

The children's first names are used to demonstrate the very rich cultural make-up of the area in which the research was carried out. (At the time of the research 19 different home languages were spoken by the children at the school and 12 of these by the children who took part in the research, these included Polish, Bengali, Spanish, Kurdish, Yoruba, French, Turkish and Sylheti amongst others.) No family names were ever used, nor were the school identified anywhere. The Head Teacher and the Chair of Governors were happy with this decision. Equally, the voices and views of the children are presented exactly as they were recorded or written, their own language is used and nothing has been changed or edited. Moreover the children were encouraged to complete the questionnaires and respond to questions by

\footnotetext{
${ }^{7}$ The earliest reference that I have found to "children being seen and not heard" comes from John Quincy Adams the 6th President of the United States of America, who in his memoire published in 1875 recalls: "My dear mother's constant lesson in childhood, that children should be seen and not heard" (1875: Vol V. xii) published by J.B. Lippincott \& Co. Philadelphia.
} 
themselves with minimal instructional support by the class teacher. They completed the questionnaires and follow up interviews were carried out during curriculum time as part of a literacy lesson on surveys in the early summer term of 2016.

\section{Data Analysis and Presentation of the Data from the Questionnaires - An Overview}

Through the use of questionnaires and interviews the children's responses have been analysed and used to enlighten the discussion surrounding the OPG legacy for London 2012. In analysing the data provided by the children the responses have been grouped using the constructivist-interpretivist stance outlined earlier. The researcher also drew upon the work of Benjamin Bloom in his Taxonomy of Learning (1956) in order to help interpret the data that the children shared. Notwithstanding the point that there has been a number of interpretations and additions to Bloom's taxonomy since his original work, see for example Harrow (1972), Dave (1975), the taxonomy serves as a very helpful guide in terms of categorising the children's responses. In his taxonomy Bloom identified three different types of educational activity, which he called domains of learning:

1. The Cognitive, which he associated with mental skills and were linked to knowledge.

2. The Affective, which was linked to growth in feelings or emotional areas and associated with attitudes.

3. Psychomotor learning was linked to the development of manual or physical activities and were associated with skills.

So for example as an answer to the question, Has the Olympic or Paralympic Games made a difference to your life or anybody that you know? Burim wrote "Yes, because looking at the Olympics teaches me how to do flips (somersaults) and to run faster." This clearly demonstrates Burim thinking about what he has seen, as he has been evidently inspired by the gymnasts and athletes. This shows Burim has been thinking about the OPGs and is linked with Bloom's cognitive learning and associated with Bloom's psychomotor domain of learning also. In relation to psychomotor learning, in answer to the same question Charlice stated "Yes, it has, knowing that people with disabilities can accomplish their goals and if they can do so, then I can accomplish my goals to (sic)" Charlice was very impressed by the hard work and dedication of what she saw at London 2012. This shows Charlice thinking and feeling deeply about the Paralympians and using Bloom's taxonomy. This response has been categorised as both cognitive and affective. 


\section{Sinking, Swimming or just Treading Water?}

In this section the researcher wanted to specifically know whether the 52 local children had learnt to swim in the four years since London 2012, and whether they had ever used the Olympic Aquatic Centre in the Olympic Park? The first lead question was to ask a closed question, Can you swim? Of the 52 respondents $44(84.6 \%)$ said that they could swim, 6 stated that they could not, and 2 children did not answer the question. The next question was to enquire; where the children had learnt to swim? Of the 44 children who could swim, 24 $(46.1 \%)$ just under half of the cohort, said that they had learnt to swim at school during swimming lessons. Other responses included whilst on holiday in Italy and Cyprus and other local swimming baths in the immediate area. Only 11 children said they had used any of the Olympic facilities and only one child had visited and used the Olympic pool. Rahim stated "I have used the Olympic swimming pool many times." It was especially pleasing that 44 of the 52 children stated that they could swim, and distances ranged from Nada who wrote "Yes I can swim just a bit" and Duane who said he could swim "40 feet", to Olivia who wrote "During lessons 12 lengths, but by myself 24 lengths," and Elif wrote "Not too sure, but I estimate about 200 metres." However during conversation it became clear that the very high success rate of the children being able to swim, had not taken place in a swimming pool or leisure centre outside of the school, but rather the head teacher was so concerned at the children's lack of opportunity to learn to swim, that she had paid to bring a transportable pool to the school. It was estimated that the overall expenditure for the London 2012 Olympic and Paralympic games was in excess of $£ 9.3$ billion sterling pounds and the overall cost of the "state of the art" Aquatic centre was $£ 269$ million sterling. In what was a bold and creative move by the head teacher and school's governing body they paid for the company Make a Splash $^{8}$ to set up and install a swimming pool in the school grounds for one entire school term at a cost of over $£ 9,000$ including the heating, lighting and maintenance of the pool for this period. In practice this meant that every child in the school went swimming and had tuition every week for 14 weeks, including the option of an after school swimming club in the evenings and at the weekends. Such was the head teacher's concerns that children at her school were leaving the school, being unable to swim, that she was prepared to use an additional funding of $9 \mathrm{~K}$ because the Olympic Aquatic centre was still proving to be out of reach. As an example of prohibitive costs posted by Greenwich Leisure Limited, (GLL) ${ }^{9}$ the company based in Greenwich south east London just across the Thames River and not in the Olympic Park, quoted a sum of $£ 1,239.70$ for $10 \times 1 \mathrm{hr}$ session tuition per class, although the cost does not include transportation to or from the centre. Now compare the sum quoted above for just one class to go swimming with the data provided in Table 1 by

\footnotetext{
${ }^{8}$ Make a Splash Swimming Initiative (2016). Retrieved from www.makeasplash.org. [Accessed: 5 September 2016]

${ }^{9}$ Greenwich Leisure Limited (2016). Retrieved from www.gll.org. [Accessed: 9 September 2016]
} 
the company who provided the pool and instructors at the school for just over $£ 9,000$.

Table 1. Make a Splash (2015)

\begin{tabular}{|l|c|c|}
\hline $\begin{array}{l}\text { Percentage of Children who } \\
\text { learnt to swim in the school } \\
\text { pool }\end{array}$ & $\begin{array}{c}\text { \% of children able to swim } \\
\text { 5m or more at the start } \\
\text { of the programme }\end{array}$ & $\begin{array}{c}\text { \% of children able to } \\
\text { swim 5m or more at the } \\
\text { end of the programme }\end{array}$ \\
\hline Year Group & $0 \%$ & $37 \%$ \\
\hline Year 1 & $12 \%$ & $64 \%$ \\
\hline Year 2 & $21 \%$ & $67 \%$ \\
\hline Year 3 & $33 \%$ & $64 \%$ \\
\hline Year 4 & $40 \%$ & $73 \%$ \\
\hline Year 5 & $46 \%$ & $88 \%$ \\
\hline Year 6 & $25 \%$ & $66 \%$ \\
\hline Average & \multicolumn{2}{|}{} \\
\hline
\end{tabular}

\section{Wider Sport Participation?}

The lead question here for the children was "Do you think that you do more sport and physical activity now as a result of the Olympic Games?" Fifteen children $(28.8 \%)$ stated that they did not do more, whereas a larger group of 29 children $(55.7 \%)$ said that they did do more including Sachel who wrote "Yes it made me do and like sport more." And Mubarak stated "Yes, and I always do as much as I can." Of the cohort 8 children did not answer the question at all. In answer to the question; has the Olympic or Paralympic Games made a difference to your life or anybody that you know? Here the researcher was hoping to find out if the legacy had impacted on friends or family in terms of employment or increased sporting participation by friends or family. The responses to this question were literally a straight split with 26 , $50 \%$ children answering negatively and the remaining 50\% all responding that it had made a difference in one form or another. For example Lisa, wrote "Definitely, I have started swimming because of the Games," Emre mentioned how the Games "had made me start running," and Nadine reported "Yes, I have even seen my neighbour's Grandpa going running." On a different note, only two children mentioned employment in relation to the Games making a difference to people they know. Josh told the researcher, "I know someone that was a guard at the Olympics," and Rahim noted that "My Dad works for the same company" referring to the company (GLL) who ran the Aquatic Centre in the Olympic Park. Perhaps this explains Rahim's earlier response that he had "used the Olympic Swimming pool many times." In contextualising the comments by the children still further Tessa Jowell the former Olympic Minister stated on the British Broadcasting Corporation's (BBC) programme 
Today $\left(6^{\text {th }} \text { July } 2015\right)^{10}$ "that the legacy had not worked, as children in schools were now doing less sport than they were in 2009," and 400,000 fewer are doing sports.

In this section, the researcher has given a brief overview, and a flavour of some of the things that the children shared. In the following section the researcher seeks to interpret and analyse the responses as a means of answering the lead research question, and the question of swimming, physical activity uptake and the Olympic legacy.

\section{Discussion, Interpretation and Analysis of the Data}

At the present time of analysing the data provided by the children, it is a very fair and clear interpretation of the data to state that no significant or observable or measurable benefit has been experienced by the children or their families in terms of economic improvement or by a re-generation of the area and environment to date.

However in terms of accessing greater sporting opportunity and experiencing an increase in physical activity, there appears to be a much brighter legacy, where perhaps for some of the children their hopes and aspirations as detailed in the work of 2011, 2014 and now 2016 may indeed be realised in the short term at the very least. At stated by Vigor et al (2004) it is the soft infrastructure not the hard infrastructure (the stadium, the swimming pool, the velodrome, or the "copper box") which is making a difference in the children's lives, but rather the Primary Premium funding, the money used by schools to improve the quality and quantity of PE and Sport provision that is making a difference to the children. The Primary PE and Sport Premium committed by the former UK Prime Minister David Cameron in $2013^{11}$, retrospectively after the completion of the OPG, to the sum of $£ 750$ million, in real terms meaning $£ 150$ million to be spent each year until 2020, guaranteed to secure an Olympic and Parlympic sporting legacy is proving to be very helpful, to schools and of great benefit to the children. It was this funding that the Head teacher used in order to ensure that the children in her school were given the opportunity to learn to swim. Jacqueline in Willow class wrote "I think the swimming [pool] should stay because children can use it to learn to swim." Cicek stated "I think the swimming pool is good for children like me to learn to swim in, and to have fun in."

The point to be made here is that the children's school now offers the children a much wider range of activities than they could previously have afforded including swimming provision. This point appears to be crucial if the funding presently available is to really make a difference, as it is the training and developing of the teaching staff long term that looks to be key.

\footnotetext{
${ }^{10}$ British Broadcasting Corporation $\left(2015,6^{\text {th }}\right.$ July) Today with Tessa Jowell, Radio 4 BBC.

${ }^{11}$ Cameron D $\left(2014,6^{\text {th }}\right.$ February) $£ 750$ boost for primary school sport. Number 10 Press Notice. Retrieved from www.bbc.co.uk/sport/press.
} 
The teachers must learn from the outside agencies and in this example the swimming coaches employed by the schools whilst the funding is in place. It is not a sustainable or effective practice (as it has been reported anecdotally) to use the outside agencies to cover teachers planning and preparation time. This will mean that schools will be in the same position as they were before the funding was pledged with many teachers lacking the training, confidence or ability to teach PE and Sports effectively. Whist The Office for Standards in Education (OFSTED) has a remit to inspect how the funding is used; it is unclear how schools will spend the money to ensure it is used to bring about long term sustainable goals. It is evidently making a difference to the children of Hackney in East London. However on a related issue in terms of the educational context (schools, teachers, the children and their parents) are continuing to receive mixed messages about the importance of PE, sport and physical activity in line with the National Curriculum's hierarchical format. September 2013 saw the introduction and rolling out of the new National Curriculum for all subjects including PE (Department for Education 2013). Surprisingly the distinction between core subjects ${ }^{12}$ and foundation subjects remains, with the core subjects being given greater value in terms of coverage and timetabling. PE continues to be a foundation subject and although a mandatory subject which has to be taught, at no point is it stipulated how much, how little or when it should be taught? The Association for Physical Education recommends a minimum of at least two hours in curriculum time ${ }^{13}$. Perhaps even more bizarrely it seems odd that a government that appears to put so much emphasis (and money) on achieving the Olympic legacy does not think it is necessary to move the status of PE from foundation status to core status. There does appear to be a contradiction of reasoning here? As stated earlier and the researcher states it again for emphasis, the latest NC in the UK in its entirety is 224 pages long and PE is located as the final subject in alphabetical order and comprises of just four pages out of the full 224 pages Have the UK policy makers "missed a trick" here in terms of giving a clear and direct message to all, that PE, sport, swimming and the Olympic legacy are valued in our ever increasing sedentary society in the early $21^{\text {st }}$ century? Why wasn't it made into a core subject?

\section{Conclusion and Recommendations}

The researcher concludes this paper by once again making the point that defining the term legacy continues to be problematic. This difficulty is compounded further if we examine the notion of time in relation to seeing

\footnotetext{
${ }^{12}$ In the UK National Curriculum, core subjects English, Math and Science are given greater weighting in terms of time-tables and curriculum coverage as opposed to foundation subjects like PE, Music, History, Art or Geography for example (Department for Education 2013).

${ }_{13}$ Association for Physical Education (2012). Retrieved from http://www.afpe.org.uk [Accessed: 23 May 2012]; Association for Physical Education (2013). Retrieved from http://www.afpe.org.uk [Accessed: 23 September 2013]
} 
whether the aims or outcomes of a legacy have been achieved. If the researcher were to critique his own work it could be argued that an examination of the Olympic legacy in 2015 is too soon to get a meaningful overview of whether it has been successful or not. Is four years long enough, or should the position be reviewed after 7 years, 10 years or even 20 years? This concern does not easily dissipate. However, the Department for Culture, Sport and Media (2015) in their publication A Living Legacy: 2010 -2015, Sport Policy and Investment have anticipated that their goals are indeed long term. They state:

"We expect that the Park will bring over 10,000 new homes (around half of which are affordable) by 2031, and over 15,000 new jobs to East London by $2025 "$ (p. 16). The first cohort of children who took part in this research in 2007 will be $29 y$ yrs old in 2025 and 35yrs old in 2031 - whether they will be living and working on the iconic Olympic Park and using the swimming pool or using the velodrome remains to be seen?

This paper adds to the body of knowledge on Olympic and Paralympic legacy for Olympics past, London 2012 and beyond.

Its uniqueness lies in the fact that children have been asked their views on two aspects of the legacy, and this has not been before as far as the researcher is aware. The data that has been presented is an overview of some of the things that were shared with the researcher, as it is their voices that are missing from many debates, and through the notion of Olympic legacy. The researcher calls for a greater involvement of learner voice as a pedagogical tool. Children are able, if given the opportunity to offer fresh insight into a range of discussions and play a part in decision making and an investment in their own lives. Leaving such practice to secondary schooling is too little, too late. It appears at best unwise, at worst invidious that the debate about the OPG legacy goes on "around" the children when they will be the inheritors of the legacy. As this paper shows the children are perfectly willing and able to speak for themselves if given the opportunity.

In terms of increased sporting and swimming opportunities for one school at least, the legacy is still alive provided that the schools continue to use the money wisely and to invest in their own teaching staff as a long term sustainable legacy, and the sporting facilities be made as accessible as possible for the next generation. One of the key findings of this research, is that the legacy from 2012 is making a difference to the development of Physical Education provision in relation to the UK National Curriculum, but it is the schools who are the catalysts in making the difference, provided the funding from the Primary Premium remains in place. Time will bear witness to the success or failure of the Olympic legacy. Quite what would happen if the funding was withdrawn is open to debate, but unless an investment in the teaching of staff is emphasised the problems will remain long term.

The researcher acknowledges that if the research work were to be critiqued the charge that children as young as 10 and 11 years old might not be the best people to ask such profound questions is a valid one, but such a charge misses the point, although the researcher would agree that one would get a much more informed and detailed response by an adult or adolescent for example. 
However, the children responded at a level commensurate with their own chronological age and that it is worthy of note in itself. See also the work of Gallahue and Ozmun (2000) who argue that it is in precisely this age range that the motor specialist phase develops mostly, which will then impact most on movements in adult life and recreational and competitive activities. By including them in such conversations and valuing what they have to say at the very least, we are sharing and demonstrating democratic practices in a very undemocratic place like a school, ${ }^{14}$ and moving away from the notion that even as young as 10 and 11 years old children are so much more than just blank slates and empty vessels.

Finally on reflection, it is worth acknowledging that this piece of research is not without weaknesses, (and the researcher has yet to see a perfect piece of research,) but what is apparent to me as a new researcher, is that researching is not a passive process, far from it. For engaging with the concept of the learner/pupil voice, the researcher has learnt so much as it is not a one way relationship, and hearing and listening can be two very different things.

\section{References}

Apple MW (1995) Education and Power (2 ${ }^{\text {nd }}$ edn.). New York and London: Routledge.

Ball S (1993) Education policy, power relations and teachers work. British Journal of Educational Studies 41(2): 106-121.

Bloom, B. (1956) Taxonomy of Education Handbook 1 \& 2: The Cognitive and Affective Domains: New York: David Mc Kay Co Inc.

Brunet F (2009) The Economy of the Barcelona Olympic Games. In G Poynter, I MacRury (eds.), Olympic Cities: 2012 and the Remaking of London (pp. 97-109). London: Ashgate Publishers.

Brunet F, Xinwen Z (2009) The Economy of the Beijing Olympic Games. An analysis of Prospects and First Impacts. In G Poynter, I MacRury (eds.), Olympic Cities: 2012 and the Remaking of London (pp. 163-182). London: Ashgate Publishers.

Burke C, Grosvenor I (2003) The School I'd like. London: Routledge.

Burr V (1995) An introduction to Social Constructionism. London: Routledge.

Cashman R (2006) The Bitter-Sweet Awakening: The Legacy of the Sydney 2000 Olympic Games. Sydney: Walla Press.

Cashman R (2011) The Sydney Olympic Park 2000-2010 History and Legacy. Sydney: Walla Press.

Costas BP (2011) The Voices of Year 6 children: their views on Physical Education, and the implications for Policy, Practice and Research. Unpublished Doctoral Thesis. Institute of Education. University of London.

Costas BP (2014) The Voices of Children, Aged 10-11 Years Old: Physical Education and the Implications for Policy, Practice, and Research in England. International Journal of Pedagogy and Curriculum 20(4): 121-131.

\footnotetext{
${ }^{14}$ See for example the work of Burke and Grosvenor (2003), entitled The School I'd Like, where children are actively encouraged to share what they like and dislike about their schools
} 
Costas BP (2016) The Voices of Children Aged Ten-and Eleven-Years-Old: London 2012 and the Olympic Legacy. Journal of Sports Pedagogy and Physical Education 7(1): 15-28.

Dave RH (1975) Developing and writing behavioural objectives. New York: Armstrong Educational Innovators Press.

Department for Culture Media and Sport (2008) Before during and after: making the most of the London 2012 Olympic Games. (The Legacy Action Plan) London, DCMS.

Department for Culture Media and Sport (2015) A Living Legacy: 2010-15. Sport Policy and Investment London, DCMS.

Department for Children Schools and Families (2009) The Independent Review of the Primary Curriculum: Final Report. London, DCSF.

Department for Education (2013) The National Curriculum HMSO. London.

Department for Education and Skills (2003) Every Child Matters DfES. HMSO London.

Duran P (eds.) (2005) The impact of the Games on tourism: Barcelona: the legacy of the games 1992-2002. M Morages. Barcelona: Centre d'Estudies Olympics UAB.

Fielding M (2004) New Wave Student Voice and the Renewal of Civic Society. London Educational Review 2(3): 197-217.

Fielding M (2008) Interrogating Student Voice: Pre-occupying purposes and possibilities. Critical perspectives in Education. London: Institute of Education, University of London.

Gallahue D, Ozmun JC (2000) Understanding Motor Development. Infants, Children, Adolescents and Adults. Boston: McGraw-Hill College.

Geertz C (1973) The interpretation of cultures. New York: Basis Books

Gold JR, Gold MM (2008) Olympic Cities: Regeneration, City Rebranding and Changing Urban Agendas. Geography Compass 2(1): 300-318.

Griffiths M, Armour K (2012) Physical Education and youth sport in England: conceptual and practical foundations for an Olympic legacy? International Journal of Sport Policy and Politics 4(2): 213-227.

Guba EG, Lincoln YS (1994) Competing Paradigms in qualitative research. In NK Denzin, YS Lincoln (Eds.), The landscape of qualitative research: Theories and issues. Illinois: Thousand Oaks Sage.

Harrow A (1972) A taxonomy of Psychomotor domain: a guide for developing behavioural objectives. New York: David McKay.

Lawton D (1996) Beyond the National Curriculum: teacher professionalism and empowerment. London: Hodder and Stoughton.

Lawton D (2000) Values and Education: A Curriculum for the $21^{\text {st }}$ Century. Paper presented at the Institute of Education: in Values and Curriculum. University of London. $1^{\text {st }}$ November 2000.

Lee S, Ghaye T, Dixon M (2013) An economic and social legacy: take note Rio. Reflective Practice 14(5): 581-583.

MacAloon JJ (2008) "Legacy" as managerial/magical discourse in contemporary Olympic affairs. The International Journal of the History of Sport 25(14): 20602071.

McIntosh MJ (2003) The Olympic Bid Process as the Starting Point of the Legacy Development. The Legacy of the Olympic Games: 1984-2000, cited in Gold JR, Gold MM (2008) Olympic Cities: Regeneration, City Rebranding and Changing Urban Agendas. Geography Compass 2(1): 300-318. 
Nello O (1997) The Olympic Village of Barcelona 92. In M De Moragas, M Lines, B Kidd (Eds.), Olympic Villages: Hundred years of Urban Planning and Shared Experiences (pp. 91-96). Lausanne: Olympic Museum, International Olympic Committee.

Panagiotopoulou R (2009) The $28^{\text {th }}$ Olympic Games in Athens 2004. In G Poynter, I MacRury (Eds.), Olympic Cities: 2012 and the Remaking of London (pp. 145162). London: Ashgate Publishers.

Penney D (2004) Physical Education. In J White (Eds.), Rethinking the School Curriculum Values, Aims and Purposes. London: Routledge.

Piper H, Garratt D (2013) Olympic Dreams and Social Realities: a Foucauldian Analysis of Legacy and Mass Participation. Sociological Research Online 18(2): 20.

Poynter G (2009) London 2012 and the reshaping of East London. In R. Imrie, L Lees, M Raco (Eds.), Regenerating London (pp. 132-151). London: Routledge.

Poynter G (2006) From Beijing to Bow Bells. Working Paper in Urban Studies. London. East London Research Institute.

Robinson K, Aronica L (2015) Creative Schools: revolutionising education from the ground up. London: Penguin Books.

Schwandt T (1994) Constructivist, interpretivist approaches to human inquiry. In NK Denzin, YS Lincoln (Eds.), The landscape of qualitative research: Theories and issues. Illinois: Thousand Oaks Sage.

Simons H (1987) Getting to know schools in a democracy: the politics and process of evaluation. Lewes: Falmer.

Simons H (1999) Evaluation democratic de institutions escolares. Madrid: Ediciones Morata.

Smit T (2002) The Eden Project. London: Bantam.

Torres CR (2011) On the Merit of the Legacy of Failed Olympic Bids. Paper written in the framework of the IOCs OSC Grant Selection committee. Retrieved from goo.gl/3XHi99. [Accessed: 6 March 2013]

Tsipras A (2015) Syriza: Political Manifesto address to the nation - (Coalition of the Left Anti-austerity Party). Oath of allegiance to the Constitution to President Karolas. Last modified 26 January 2015.

Vigor A. Mean, M, Tims, C. (2004) After the Gold Rush. London: IPPR Demos. Available at http://www.demos.co.uk/files/AftertheGoldRush.pdf Accessed on $6^{\text {th }}$ March 2014.

Westminster Education Forum (2012, March 8) Reviewing the Physical Education Curriculum The National Curriculum Seminar Series. London.

White J (2004) Rethinking the School Curriculum: Values Aims and Purposes. London: Routledge.

White J (2007) What schools are for and why. Impact (14): vi-51. 